\title{
Original Research \\ Knowledge and sources of information about medicines among adolescents in Malta
}

\author{
Rita DARMANIN ELLUL, Maria CORDINA, Anton BUHAGIAR, Anthony FENECH, Janet MIFSUD. \\ Received (first version): 17-Mar-2008 Accepted: 18-Aug -2008
}

\begin{abstract}
${ }^{*}$
Objective: To investigate knowledge of medicines and sources of information about medicines among adolescents in Malta.

Methods: A self-administered questionnaire was used to survey knowledge of medicines and information sources among adolescents attending secondary schools in Malta. A random stratified sample design generated a sample size of 514 students. Knowledge of medicines was investigated by questions that included topics about the efficacy of medicines, proper communication during a medical consultation, the safety of medicines, antibiotic use and pictograms.

Results: The analytical sample, of which $53.8 \%$ were girls, was made up of 474 students, aged 14 16 years. The students obtained a mean score of 22.92 points $(S D=4.31$ ) out of a maximum of 32 points for medicine knowledge. More than $30.0 \%$ of the respondents did not mark the correct answer for $40.6 \%$ of the questions that investigated knowledge of medicines. The family physician, community pharmacist and parents were the sources of information that were mostly cited. A proportion of $4.4 \%$ had obtained information from the teacher. A quarter of the respondents $(24.7 \%)$ had obtained information from friends/schoolmates, young relatives or the media, generally television (17.3\%). Conclusion: Although the level of knowledge about medicines among this study sample of Maltese students was good, there appeared to be particular misconceptions with regard to important aspects associated with the proper use of medicines. These findings highlight the need to educate adolescents about the proper use of medicines. The most important information providers about medicines appeared to be the physician, pharmacist and parents. It is being suggested that education campaigns should be organized in order to help parents guide adolescents on how to use medicines appropriately. In addition, adolescents would benefit if more information about the proper use of medicines would be disseminated by means of
\end{abstract}

\footnotetext{
Rita DARMANIN ELLUL. MSc. Department of Clinical Pharmacology and Therapeutics, University of Malta. Msida (Malta).

Maria CORDINA. PhD. Department of Pharmacy, University of Malta. Msida (Malta).

Anton BUHAGIAR. PhD. Department of Mathematics, University of Malta. Msida (Malta).

Anthony FENECH. PhD. Department of Clinical

Pharmacology and Therapeutics, University of Malta. Msida (Malta).

Janet MIFSUD. PhD. Department of Clinical

Pharmacology and Therapeutics, University of Malta Msida (Malta).
}

television programs and school-based health education curricula.

Keywords: Adolescent. Consumer Health Information. Knowledge. Malta.

\section{CONOCIMIENTO Y FUENTES DE INFORMACIÓN SOBRE MEDICAMENTOS ENTRE LOS ADOLESCENTES EN MALTA}

\section{RESUMEN}

Objetivo: Investigar el conocimiento y las fuentes de información sobre medicamentos entre adolescentes en Malta.

Métodos: Se usó un cuestionario auto-administrado para investigar el conocimiento sobre medicamentos y las fuentes de información entre adolescentes de escuelas secundarias en Malta. Un diseño de muestra aleatorio estratificado generó una muestra de 514 estudiantes. El conocimiento sobre medicamentos se investigó con preguntas que incluían temas sobre la eficacia de los medicamentos, la correcta comunicación en la consulta médica, la seguridad de los medicamentos, el uso de antibióticos y los pictogramas. Resultados: La muestra analítica, de las cuales $53,8 \%$ eran mujeres, se construyó con 474 estudiantes de 14 a 16 años. Los estudiantes obtuvieron una puntuación media de 22,92 puntos $(\mathrm{DE}=4,31)$ de un máximo de 32 puntos para el conocimiento de medicamentos. Más del 30,0\% de los respondentes no marcó la respuesta correcta para el $40,6 \%$ de las preguntas del cuestionario. El médico de familia, el farmacéutico comunitario y los padres fueron las fuentes de información más citadas. Un 4,4\% había obtenido la información del profesor. Un cuarto de los respondentes $(24,7 \%)$ había obtenido la información de amigos/compañeros, parientes jóvenes o los medios de comunicación, generalmente la televisión $(17,3 \%)$.

Concusión: Aunque el nivel de conocimientos en esta muestra de estudiantes malteses fue bueno, pareció que había errores de concepto específicos en torno a importantes aspectos relacionados con el uso correcto de medicamentos. Estos hallazgos ensalzan la necesidad de educar a los adolescentes en al uso correcto de medicamentos Los proveedores de información sobre medicamentos más importantes parecieron ser el médico, el farmacéutico y los padres. Se sugiere que deberían organizarse campañas de información para ayudar a que los padres guíen a los adolescentes en cómo utilizar los medicamentos apropiadamente. 
Además, los adolescentes se beneficiarían si se diseminase más información sobre el uso correcto de medicamentos por televisión y en el currículo de la educación escolar.

Palabras clave: Adolescente. Información sanitaria a consumidor. Conocimiento. Malta.

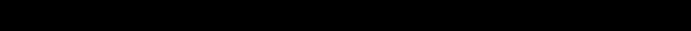

\section{INTRODUCTION}

The use of medicines particularly that which occurs without adult guidance, for the treatment of health problems, has been reported to be common practice during adolescence. ${ }^{1-12}$ With the development of formal operational thinking, the adolescent often engages in autonomous health behaviours. ${ }^{13}$ The query emerges not as to whether adolescents should self-medicate but how to ensure that adolescents possess appropriate knowledge to use medicines responsibly.

From the sparse literature available on the subject, it has often been suggested that knowledge of medicines among adolescents is inadequate. .,8,14-17 $^{-1}$ For instance, in a questionnaire designed to assess the knowledge of medicines among 15-17 year-old adolescents in Germany, the average score that had been obtained did not exceed $5.74(S D=1.89)$ out of 13 possible points. ${ }^{8}$ In another study carried out in Canada among 12-15 year-old adolescents who had complained of stomach pain during the preceding 3 months, $11.2 \%$ of the participants had used ibuprofen and $13.6 \%$ had used aspirin thereby possibly exacerbating their pain rather than relieving it. $^{4}$

In addition, studies have shown that adolescents possess poor basic knowledge about antibiotic use. $8,14,15$ In Germany, only $32 \%$ of $15-17$ year-olds had given the correct definition for 'antibiotic'. In Kenya, antimalarials were commonly used by $11-17$ year-olds for symptoms of the common cold. ${ }^{14}$ Poor knowledge could lead to the improper use of commonly used medicines which in turn may lead to serious repercussions. Furthermore, attitudes towards medicines that are formed at a young age may affect how medicines are used later on in adulthood. $^{18}$

Early adolescence is also characterized by the transition from a family-centered environment, to a broader environment open to more influences. ${ }^{19}$ The literature has shown that adolescents obtain information about medicines from a variety of sources such as family members, friends, physicians, nurses, pharmacists, the media, teachers and the medicine package insert. ${ }^{4,8,11}$

In the specific case of Malta, since this is a small island with a very high population density ${ }^{20}$, spread of information also takes place quickly by word of mouth. Moreover, since Malta has 2 official languages, Maltese and English, it is possible for adolescents to have access to a wide variety of information sources.
Information on the sources from which adolescents obtain information about medicines helps educators identify the areas that need to be targeted in the dissemination of information about medicines to adolescents.

This study was thus aimed at investigating adolescents' knowledge of medicines in a small island state, Malta. This research investigated: (1) the level of basic knowledge about medicines, and (2) the sources of information about medicines which are accessed among adolescents in Malta.

\section{METHODS}

A self-administered questionnaire was used to survey knowledge and sources of information about medicines among 14-16 year-old adolescents attending fourth-form public school Junior Lyceums during the period from March to May 2005. Entrance to Junior Lyceums is through a competitive exam, thus making the students a very homogenous group in terms of mental ability and language fluency. The total population of fourthformers attending Junior Lyceums in Malta in 2005 was 1808. This represented $33.3 \%$ of the total adolescents in that age range in Malta. In order to estimate the number of students required to answer the questionnaire that would ensure statistical validity, the most sensitive question in the questionnaire was determined by a pilot study, assuming $95 \%$ confidence and $80 \%$ power. This was taken to have an expected value of $3.7 \%$, thus a sample size of 455 students was calculated using Statcalc in Epi Info (Version 6), accepting an error of $1.5 \%$.

In order to obtain a representative sample, the whole population of fourth-formers attending Junior Lyceums in Malta was stratified by gender and geographical area of residence. Whole classes were than selected by random sampling in order to ensure that the calculated target sample size was reached. The population size generated by stratified random sampling was 514 students distributed over 8 schools. Data collection was carried out during regular class periods under the investigator's supervision. Informed consent was obtained before distributing the questionnaires to the students. The self-administered questionnaires were answered anonymously by the students and returned in sealed envelopes. The students took approximately 30 minutes to complete the questionnaire. Sociodemographic information was collected on gender, month and year of birth and area of residence of the students. Social class variation was measured by means of a family affluence scale that had been established by the World Health Organization (WHO). ${ }^{21,22}$

The data presented in this specific study which formed part of a larger study, is restricted to the descriptive analysis of the following items: knowledge about medicines and sources of information about medicines.

In order to check for congruency of meaning, the questionnaire that had been originally drafted in English, was translated to Maltese and back- 
translated to English. Ethical approval for the study was obtained from the Ministry of Education and the Research Ethics Committee of the University of Malta. The questionnaire was pre-tested with a small number of students to ensure clarity of meaning.

A set of questions was used to examine basic knowledge about medicines. Thirty-two questions were grouped under 16 stem questions to make the questionnaire more interesting as suggested by the students during the questionnaire pre-test (see Table 1). For most of the questions (Table 1 , question numbers $1-3,6-11,14)$, the students had to mark 1 of 3 options (yes, no, don't know). For the rest of the questions, the students had to mark one or more responses from a multiple response set.

The questionnaire was primarily based on the "Guide to Developing and Evaluating Medicine Education Programs and Materials for Children and Adolescents". ${ }^{23}$ This guide is aimed to increase knowledge about medicines among children and adolescents and prepare them to become rational users of medicines. It had been based on recommendations of the USP Ad hoc Advisory Panel on Children and Medicines and on information obtained from interviewing children, young adolescents and teachers. According to this guide, by the age of 14 years, adolescents should have knowledge about whether efficacy of a medicine is related to colour and shape of a tablet; the different dose forms that exist and ways of taking medicines; the possibility of a medicine having more than one name; how medicines work and what happens to medicines in the body; how to ask questions of health care professionals about medicines; how one could tell the difference between medicines for children and medicines for adults; proper storage of medicines and observation of expiry date; side effects of medicines; the fact that antibiotics cannot be used to treat viral infections; and the importance of taking full courses of antibiotics. This guide also provides a list of pictograms which children and adolescents should learn to recognize. All of these themes above were addressed in the questionnaire designed for the present study (Table 1, questions 1-5, 9, 12, 13-16).

In our study, a question was also asked about whether commonly used over-the-counter medicines could cause harm if taken in excess (Table 1, question 10). This question was taken from an online quiz in a health educational website. ${ }^{24}$ The other questions were designed by the authors themselves based on recommendations in published research on adolescents (Table 1, question 8) and information supplied in TeensHealth (Table 1, question $6,7,11$ ) (an accredited and health professional reviewed website for adolescents). ${ }^{8,25}$

A further part of the questionnaire consisted of a checklist designed to investigate the sources of information about medicines which had been accessed by the adolescents. This checklist included the medicine package, parents/adult relatives, the community pharmacist, friends/ schoolmates, the radio, television, magazines, teachers, young relatives or the family physician. Since Maltese adolescents do not receive any formal education about medicines, it was believed unethical by the authors to include the internet in this list. The authors did not want to be suggestive for the reason that, using the internet, it is often difficult to find reliable and understandable information without guidance. Instead, a free response question asked about other sources of information which had been accessed. A closedended question then asked the respondents whether they wished to learn more about medicines.

The data was processed using PC90 (BMDP Statistical Software, 1990). Percentages were calculated for all the nominal categories of the replies given. In addition, the total and mean score for knowledge about medicines were calculated for all the study population and separately for boys and girls. When calculating the scores, a value of 1 point was awarded for each correct answer for medicine knowledge, making up a total of 32 points. Means in the data provided are presented together with the standard deviation about the mean. Analysis of variance was carried out to estimate statistical gender differences in mean scores obtained for knowledge of medicines. The level of statistical significance was taken at $p=0.05$.

The students were grouped into 2 categories according to their response to the question about sources of information about medicines: those students who had obtained information from adults i.e. the family physician, community pharmacist, teacher or parents/adult relatives and those students who had obtained information from young relatives, friends/ schoolmates or the mass media (television, radio, magazines). The proportion of students in each of these categories was calculated.

Since the participants did not consistently respond to every question on the questionnaire, there may be differences in the value of $\mathrm{n}$ (the total population of respondents), depending on the question.

\section{RESULTS}

A total of 477 students were present on the days of data collection and all of these returned the questionnaire. Three of the questionnaires were not correctly submitted by the respondents, leading to an actual sample size of 474 . The age of the students ranged from 14 to 16 years (mean 15.22 years, $S D=0.41$ years). A total of 255 students $(53.8 \%)$ were girls. From a total of 472 respondents, $175(37.1 \%), 254(53.8 \%)$ and $43(9.1 \%)$ students ranked low, medium and high respectively according the WHO family affluence scale. ${ }^{21,22}$

Table 1 provides information about the percentage correct responses for knowledge of medicines. Following completion of the questionnaire, the students obtained a mean of 22.92 points $(S D=4.31)$ out of a maximum of 32 points for medicine knowledge. The majority of the students answered correctly to most of the questions. However, more than $30.0 \%$ of the respondents did not mark the correct response for questions associated with efficacy of medicines, the fate of 
medicines in the body, proper communication during a medical consultation, the safety of common over-the-counter medicines, storage and shelf-life of medicines and antibiotic use (Table 1, questions 1a, $1 \mathrm{~b}, 3,4 \mathrm{a}, 5 \mathrm{a}, 5 \mathrm{~d}, 5 \mathrm{e}, 10 \mathrm{a}, 10 \mathrm{c}, 11 \mathrm{c}, 12,14$ and 15).
These questions constituted $40.6 \%$ out of a total of 32 questions in the questionnaire. Girls obtained a higher mean score $(p=0.007)$ in knowledge of medicines $(23.42$ points, $\mathrm{SD}=3.73)$ than boys $(22.35$ points, $S D=4.85$ ).

\begin{tabular}{|c|c|c|c|}
\hline $\begin{array}{l}\text { Question } \\
\text { number }\end{array}$ & Questions related to knowledge about medicines & $\begin{array}{l}\text { Correct } \\
\text { response }\end{array}$ & $\begin{array}{l}\text { No. }(\%) \text { of correct } \\
\text { answers }(n=474)\end{array}$ \\
\hline 1 & $\begin{array}{l}\text { Do the following characteristics affect the action of a medicine in } \\
\text { the body? }\end{array}$ & & \\
\hline a. & shape of a tablet & No & $222(46.8 \%)$ \\
\hline b. & colour of a tablet & No & $219(46.2 \%)$ \\
\hline 2. & $\begin{array}{l}\text { Can a particular medicine exist in more than one form (e.g., in } \\
\text { tablet form and in the form of a syrup)? }\end{array}$ & Yes & $349(73.6 \%)$ \\
\hline 3 & $\begin{array}{l}\text { Can a form containing a particular medicine have more than one } \\
\text { name? }\end{array}$ & Yes & $209(44.1 \%)$ \\
\hline 4 & $\begin{array}{l}\text { Mark the correct sequence of statements with regard to what } \\
\text { happens to a tablet once it is taken by mouth: }\end{array}$ & & \\
\hline a. & $\begin{array}{l}\text { medicine travels in the blood to the organs where it produces an } \\
\text { effect }\end{array}$ & $\mathrm{b}$ & $328(69.2 \%)$ \\
\hline b. & medicine passes from the intestines into the blood & $a$ & $346(73.0 \%)$ \\
\hline c. & $\begin{array}{l}\text { medicine is usually changed into an inactive product and } \\
\text { eliminated from the body }\end{array}$ & C & $406(85.7 \%)$ \\
\hline 5. & $\begin{array}{l}\text { Tick the questions which you should ask the physician if he/she } \\
\text { suggests you need to take a new medicine: }\end{array}$ & & \\
\hline a. & what does the medicine do? & $\sqrt{ }$ & $281(59.3 \%)$ \\
\hline b. & for how long will I take it? & $\sqrt{ }$ & $390(82.3 \%)$ \\
\hline c. & how and at what time should I take it? & $\sqrt{ }$ & $402(84.8 \%)$ \\
\hline d. & $\begin{array}{l}\text { what are the possible problems caused by the medicine and } \\
\text { what should I do if I get one? }\end{array}$ & $\sqrt{ }$ & $248(52.3 \%)$ \\
\hline e. & what should I do in case I forgot the tablet? & $\sqrt{ }$ & $160(33.8 \%)$ \\
\hline 6. & $\begin{array}{l}\text { Is it important to ask the following questions to the physician or } \\
\text { pharmacist when you tell him/her about your health problem? }\end{array}$ & & \\
\hline a. & whether you are taking any other medicine & Yes & $422(89.0 \%)$ \\
\hline b. & whether you are allergic to any medicine & Yes & $416(87.8 \%)$ \\
\hline 7. & Can alcohol drinking affect how a medicine works in the body? & Yes & $427(90.1 \%)$ \\
\hline 8. & $\begin{array}{l}\text { Does a pregnant woman need to ask a physician's advice before } \\
\text { taking medicine? }\end{array}$ & Yes & $451(95.1 \%)$ \\
\hline 9. & Whether sick children are given the same medicine as adults & No & $422(89.0 \%)$ \\
\hline 10. & $\begin{array}{l}\text { Whether the following medicines cause harm if too much of them } \\
\text { is taken: }\end{array}$ & & \\
\hline a. & vitamins & Yes & $131(27.6 \%)$ \\
\hline b. & paracetamol & Yes & $334(70.5 \%)$ \\
\hline c. & cough medicines & Yes & $266(56.1 \%)$ \\
\hline 11a. & Do some medicines have to be kept in the refrigerator? & Yes & $398(84.0 \%)$ \\
\hline 11b. & Do heat and direct sunlight damage medicines? & Yes & $397(83.8 \%)$ \\
\hline 11c. & Is the bathroom a good place for storage of medicines? & No & $214(45.1 \%)$ \\
\hline 12. & $\begin{array}{l}\text { If a bottle of eye drops is opened, when would it be unsuitable } \\
\text { for reuse given that the expiry date is in } 2 \text { years' time: after } 1 \\
\text { month, unless stated differently on the label/ after } 6 \text { months/ } \\
\text { after } 2 \text { years. }\end{array}$ & The $1^{\text {st }}$.option & $156(32.9 \%)$ \\
\hline 13. & $\begin{array}{l}\text { The side effects of a medicine are the unwanted/wanted effects } \\
\text { that a medicine produces in the body }\end{array}$ & unwanted & $379(80.0 \%)$ \\
\hline 14. & Are antibiotics always necessary to be cured? & No & $311(65.6 \%)$ \\
\hline 15. & $\begin{array}{l}\text { If the physician prescribes an antibiotic } 4 \text { times a day for a total } \\
\text { of } 5 \text { days, what would you do if you start feeling better after } 3 \\
\text { days? } \\
\text { Stop taking the medicine completely/Continue taking the } \\
\text { medicine but less than } 4 \text { times a day/Continue taking the } \\
\text { medicine } 4 \text { times a day for } 5 \text { days. }\end{array}$ & The $3^{\text {rd }}$.option & $304(64.1 \%)$ \\
\hline
\end{tabular}

Respondents $(n=473)$ reported a variety of sources of information about medicines (Figure 1). The most common sources were the family physician, community pharmacist and parents/adult relatives. Information about medicines from teachers and young relatives were not listed to the same extent. On grouping the data, the number of respondents who reported having obtained information from an adult (i.e. either from the family physician, community pharmacist, teacher or parents/adult relatives), was $450(95.1 \%$ of the total). On the other hand, 117 respondents $(24.7 \%)$ reported that they had obtained information from informal sources namely the media (television, radio and magazines), friends/schoolmates or young relatives. The free response question as to whether the students had 
accessed other information sources, was answered by only 2 students who mentioned the internet. The majority of respondents, $326 \quad(69.5 \%, n=469)$ answered that they were interested to learn more about medicines.

\section{DISCUSSION}

This study has certainly led to a better understanding of knowledge about medicines among adolescents in Malta. However, the scarcity of and differences in published studies in this field, renders it difficult for comparisons with other countries to be drawn. The students obtained a mean of 22.92 points $(S D=4.31)$ out of a maximum of 32 points for medicine knowledge. This indicates that the students in the sample had a good knowledge level. This contrasts with research among 15-17 year-old adolescents in Germany where the average score that had been obtained in a questionnaire designed to assess knowledge of medicines had been $5.74 \quad(S D=1.89)$ out of 13 possible points. ${ }^{8}$ Differences in the type of questions asked and the style of questioning could have contributed to these differences. In the present study all of the questions in the knowledge scale were closed-ended as compared to the more openended style that had been adopted in some of the questions in the German study. In addition, since the study that had been carried out in Germany had been a pilot study, the sample size had been limited.

\begin{tabular}{|c|c|c|c|}
\hline $\begin{array}{l}\text { Question } \\
\text { number }\end{array}$ & Questions related to knowledge about medicines & $\begin{array}{l}\text { Correct } \\
\text { response }\end{array}$ & $\begin{array}{l}\text { No. }(\%) \text { of correct } \\
\text { answers }(n=474)\end{array}$ \\
\hline 16. & Match the correct pictogram to their correct meaning. & & \\
\hline a. & & $\begin{array}{l}\text { place in lower } \\
\text { eyelid }\end{array}$ & $455(96.0 \%)$ \\
\hline b. & & shake well & $457(96.4 \%)$ \\
\hline c. & & $\begin{array}{l}\text { take with } \\
\text { meals }\end{array}$ & $458(96.6 \%)$ \\
\hline d. & & $\begin{array}{l}\text { take } 2 \text { times a } \\
\text { day }\end{array}$ & $452(95.4 \%)$ \\
\hline e. & & $\begin{array}{l}\text { take at } \\
\text { bedtime }\end{array}$ & $456(96.2 \%)$ \\
\hline
\end{tabular}

Most of the students in the present study responded correctly to questions about many aspects of medicines (Table 1$)$. The majority $(73.6 \%)$ of the respondents in this study knew that a particular medicine could exist in more than one form and a total of $89.0 \%$ knew that sick children are not given the same medicines as adults. These results are similar to those obtained from qualitative studies among adolescents in the US. ${ }^{16}$ The proportions of students in this study who replied that they would ask the physician for how long they should take a prescribed medicine $(82.3 \%)$ and how and at what time they should take this medicine $(84.8 \%)$ were higher than those obtained for similar questions in an online quiz on a teenage health website $(57 \%$ and $64 \%$ respectively). ${ }^{26}$ This difference in response rates could have stemmed from the fact that the online quiz could be answered by children as young as 11 years old. Although it has been advocated that individuals should learn how to ask questions of physicians even at the early age of 6 , one should bear in mind that further cognitive, language and socio-emotional development takes place as an individual grows older. ${ }^{23,27}$

On the other hand, the present study showed how knowledge was insufficient about various important aspects of use of medicines. For instance, almost $30.0 \%$ of the students were unaware that paracetamol caused harm if taken in excess. Published research carried out in other countries had shown a lack of awareness of the lethal potential of paracetamol by $10-43 \%$ of adolescents. $^{28,29}$ The widespread use, ease of access and the massive advertisement campaigns of painkillers, might give the illusion that paracetamol is an innocuous medicine. 4,5,10,30 $^{4}$

In addition, more than $30.0 \%$ of the students did not give the correct response to $40.6 \%$ of the questions that investigated knowledge of medicines including 
questions related to efficacy of medicines. For instance, the majority of students were unaware that a particular medicine could have more than one name and a substantial proportion did not know that the shape and colour of tablets did not have an effect on the action of a medicine in the body. In addition, many students missed out on some important questions which should be asked of the physician when being given a prescribed medicine. Similar observations have been reported in the literature. $^{26}$

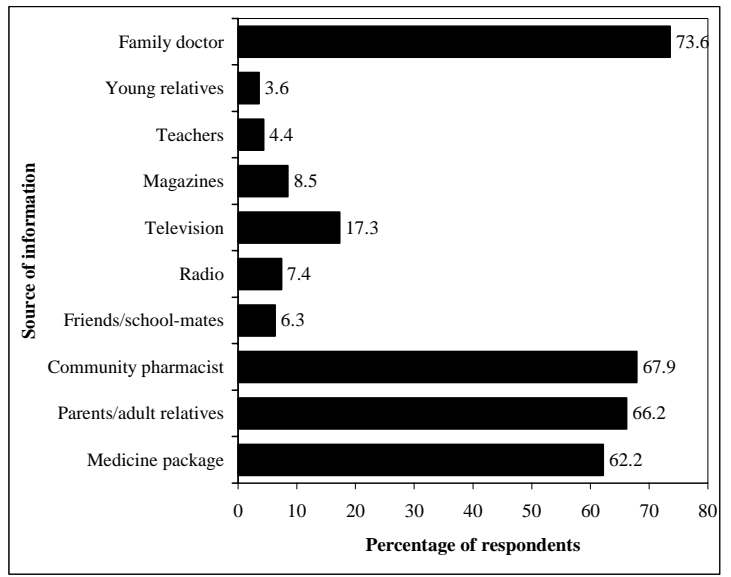

Figure 1. Bar graph depicting the sources of information about medicines that had been accessed by the adolescents in the study $(n=473)$.

Information about the storage of medicines seemed to be lacking among the participants in this study. Only $45.1 \%$ were aware that the bathroom was not a suitable place for the storage of medicines. Bathrooms are generally humid places often characterized by rises in temperature that contribute to the deterioration of medicines before the manufacturer's shelf life. A possible contributing factor for this misconception about the storage of medicines among the study sample may possibly be due to the bad medicine storage practices that adolescents observed at home. In a study carried out across 8 countries, the percentage of total medicines kept in the bathroom ranged from $1 \%$ to $58 \%{ }^{31}$

Misconceptions were also evident in the case of the harm caused by common over-the-counter medicines. Only $56.1 \%$ of the participants were aware that cough medicines could be harmful if taken in excess. In addition, substantial proportions of students did not know that antibiotics were not always necessary in order to be cured and that the whole course of antibiotic had to be taken even if one started to feel better. These beliefs could have been passed on by observed familial patterns of use of medicines. ${ }^{32}$ In a qualitative study carried out in Australia, sedating antihistamines, such as cough and cold preparations, had been the most common over-the-counter medicines that parents administered to their children. These parents had been using these medicines to alter the behaviour or induce sleep in children, rather than for the intended purpose. Bauchner et al reported that in an investigation carried out in the US, $48 \%$ of paediatricians were often pressured by parents to prescribe antibiotics when their children were ill even though antibiotics were not indicated. ${ }^{33}$ In another study carried out to study adherence to the most recent course of antibiotics among individuals aged 18 years and over and among mothers of children in 9 countries, only $75 \%$ claimed that they actually took all daily doses and only $69 \%$ of the patients reported to have taken the course to the end. $^{34}$

Girls in this study showed a greater tendency to be knowledgeable about medicines than boys. This is substantiated by research among adolescents in Germany. ${ }^{8}$ The reason for this gender difference could be the more active predisposition of girls in obtaining information from medical professionals. ${ }^{16,26}$

The students in this study reported having obtained information about medicines primarily from the family physician and community pharmacist (Figure 1 ). These findings contrast with those reported for studies carried out in other countries. ${ }^{4,11}$ In Canada, only $14.8 \%-26.5 \%$ of adolescents had obtained their information from the physician/nurse. In Kuwait, the proportions of students who had obtained their information from the physician and pharmacist were $57 \%$ and $1 \%$ respectively. The present findings suggest that the educative role of the physician and pharmacist had been relatively much more recognized among the Maltese adolescents in the study sample. In addition, these findings may reflect the high accessibility of family physicians and community pharmacists in Malta.

It is also notable that in the present study, the proportion of students who had sought information from parents/adult relatives $(66.2 \%)$ was comparable to the proportion of students who had obtained information from the community pharmacist. This prominent role of parents had been previously reported in other countries. ${ }^{4,11,12,16}$ Parents need to be encouraged to be good role models for children with respect to the correct use of medicines. ${ }^{23}$ This underlines the importance of providing information to parents which will help them to guide their children on how to use medicines properly. ${ }^{35}$ On the other hand, the teacher played a very minor role as a source of information about medicines among the study population. This is concordant with the findings of a qualitative study previously carried out in Malta and other quantitative research carried out in Canada where the proportion of adolescents who had obtained information from the teacher was $0.9 \%$ $3.6 \%$. ${ }^{4,36}$ Since adolescents spend a great deal of their time at school, teachers can contribute more to educating students about the proper use of medicines, provided that they are given the appropriate training. ${ }^{35}$ In addition, school health curricula need to be updated in order to educate adolescents on how to become knowledgeable consumers of medicines. Indeed the majority of respondents in this study expressed the wish to learn more about medicines.

A considerable proportion of the respondents $(24.7 \%)$ had obtained information about medicines from informal sources such as television. This 
finding is of concern, in view of the strong relationship that has been reported between higher levels of television viewing and frequent consumption of over-the-counter medicines. ${ }^{37}$ The popularity of television in this regard had been previously documented in a study carried out in Kuwait where the proportion of adolescents who had obtained information about medicines from television was much higher $(35.5 \%) .{ }^{11}$ Variations between countries could stem from differences in regulations governing medicine advertising.

It is interesting to note that only 2 students specified the internet as a source of information about medicines. This finding shows that Maltese students do not consider the internet an important source of information about medicines. However, in a study carried out in Kuwait, the internet was accessed by a substantial proportion (20.0\%) of adolescents. ${ }^{11}$ In addition, in a qualitative study among adolescents in the UK and the US, many students reported that the internet had been their primary general source of information. ${ }^{38}$ These variations may stem from the fact that cultural differences may exist between adolescents in different countries. The importance of the internet as a source of information is not to be underestimated, provided that adolescents are supervised at a young age and guided to use informative and reliable websites about health and medicines.

This study has both its strengths and limitations. A major strength of this study is that the gender distribution and socioeconomic status of the students was concordant with national data. ${ }^{22,39}$ This observation indicates that the findings in the study sample are likely to be representative of the whole population of 15 year-olds in Malta.

This study also had its limitations. A fixed standardized questionnaire limits the depth and coverage of measurements. Future work, involving qualitative methods can be used to compliment this study in order to reach a better understanding of knowledge about medicines among adolescents. ${ }^{40}$ It was not possible to conduct individual non-response studies with students who were absent on the days of data collection because of the requirement of anonymity. According to the information in school records, these students were away due to sickness. However, considering that almost $93.0 \%$ of the enrolled selected population was present, it is probable that the present data may only slightly misrepresent the use of medicines by Maltese adolescents.

\section{CONCLUSIONS}

The results of this study show that adolescents in Malta have a good level of knowledge of medicines. However, many adolescents appeared to have misconceptions with regard to factors associated with efficacy of medicines, the fate of medicines in the body, proper communication during a medical consultation, the safety of common over-the-counter medicines, storage and shelf-life of medicines and antibiotic use. These findings highlight the need for educating Maltese adolescents about the proper use of medicines and the majority of the respondents did express the wish to learn more about medicines. The most important information providers about medicines for Maltese adolescents appear to be the physician, pharmacist and parents. The role of the physician and pharmacist as information providers needs to be reinforced and it is being suggested that education campaigns are set up to help parents guide their children how to use medicines properly. In addition, adolescents would benefit if more information about the proper use of medicines would be disseminated in an appropriate manner through television programs and school-based health education curricula. Such measures could help adolescents grow into knowledgeable consumers, capable of making rational choices about medicines.

\section{ACKNOWLEDGEMENTS}

The authors would like to thank Dr. Andrew Amato Gauci, MD, MSc, from the European Centre for Disease Prevention and Control (ECDC), Stockholm, Sweden and Dr. Doriette Soler, MD, MSc from the Department of Health, Malta, for their help in planning this study.

\section{CONFLICT OF INTEREST}

The authors have no personal, professional or financial interests related to the material in the manuscript.

\section{References}

1. Schirm E, van den Berg $P$, Gebben $H$, Sauet $P$, de Jong-van den Berg L. Drug use of children in the community assessed through pharmacy dispensing data. Br J Clin Pharmacol. 2000;50(5):473-478.

2. Dengler R, Roberts H. Adolescents' use of prescribed drugs and over-the-counter preparations. J Public Health Med. 1996;18(4):437-442.

3. Campbell A, McGrath PJ. Use of medication by adolescents for the management of menstrual discomfort. Arch Pediatr Adolesc Med. 1997;151(9):905-913.

4. Chambers CT, Graham JR, McGrath PJ, Finley A. Self-administration of over-the-counter medication for pain among adolescents. Arch Pediatr Adolesc Med. 1997;151(5):449-555.

5. Darmanin Ellul R, Cordina M, Buhagiar A, Fenech A, Mifsud J. Health complaints and use of medicines among adolescents in Malta. Pharm Pract [Internet]. 2008; 6(3): 165-170.

6 Geissler PW, Nokes K, Prince RJ, Achieng Odhiambo R, Aagaard-Hansen J, Ouma JH. Children and medicines: selftreatment of common illnesses among Luo schoolchildren in western Kenya. Soc Sci Med. 2000;50(12):1771-1783. 
7. Lau TF, Yu A, Cheung JCK, Leung SF. Studies on common illnesses and medical care utilization patterns of adolescents in Hong Kong. J Adolesc Health. 2000;27(6):443-452.

8. Stoelben S, Krappweis J, Rossler G, Kirch W. Adolescents' drug use and drug knowledge. Eur J Pediatr. 2000;159(8):608-614.

9. Geckova A, Tuinstra J, Pudelsky M, Kovarova M, van Dijk JP, Groothoff JW, Post D. Self-reported health problems of Slovak adolescents. J Adolesc. 2001;24(5):635-645.

10. Hansen $E H$, Holstein BE, Due $P$, Currie CE. International survey of self-reported medicine use among adolescents. Pediatrics. 2003;37(3):361-366.

11. Abahussain E, Matowe LE, Nicholls PJ. Self-reported medication use among adolescents in Kuwait. Med Princ Pract. 2005;14(3):161-164.

12. da Silva C, Giugliani ER. Consumption of medicines among adolescent students: a concern. J Pediatr (Rio J). 2004;80(4):326-332.

13. lannotti RJ, Bush PJ. The development of autonomy in children's health behaviours. In: Sussman EJ, Feagans W, Ray W, editors. Emotion, Cognition, Health and Development in Children and Adolescents. New York: Erlbaum; 1989. p. 5374.

14. Geissler PW, Meinert L, Prince R, Nokes C, Aagaard-Hansen J, Jitta J, Ouma JH. Self-treatment by Kenyan and Ugandan schoolchildren and the need for school-based education. Health Policy Plan. 2001;16(4):362-371.

15. Hameen-Anttila K, Juvonen M, Ahonen R, Bush PJ, Airaksinen M. How well can children understand medicine related topics? Patient Educ Couns. 2006;60(2):171-178

16. Menacker F, Aramburuzabala P, Minian N, Bush PJ, Bibace R. Children and Medicines: What they want to know and how they want to learn. J Soc Adm Pharm. 1999(1);16:38-52.

17. Sloand B, MacLeod KM, Vessey JA. Children and self-medication: implications for primary care. Pediatr Nurs. 1997;23(6):601-605.

18. Bush PJ. Let's teach children about medicines. International Pharmacy Journal. 1990;4(5):208-211.

19. Due P, Lynch J, Holstien B, Modvig J. Socioeconomic health inequalities among a nationally representative sample of Danish adolescents: the role of different types of social relations. J Epidemiol Community Health. 2003;57:692-698.

20. Research and methodology unit. Census of population and housing 2005: Preliminary report. Malta: National statistics office; 2006.

21. HBSC focus groups. International standard version of 2001/02 HBSC mandatory questionnaire. In: Currie C, Samdal O, Smith B, editors. Health behaviour in school-aged children: a World Health Organization cross-national study. Research protocol for the 2001/02 Survey. Edinburgh: University of Edinburgh; 2001. p. 213-234.

22. Boyce W, Dallago L. Socioeconomic inequality. In: Currie C, Roberts C, Morgan A, Smith R, Settertobulte W, Samdal O, Barnekow Rasmussen V, editors. Young people's health in context. Health behaviour in school-aged children (HBSC): international report from the 2001/2002 survey. Copenhagen: World Health Organisation; 2004. p. 13-25.

23. USP Ad Hoc Advisory Panel on Children and Medicines. Guide to developing and evaluating medicine education. Programs and materials for children and adolescents. [Internet]. US:USP;1998 [cited 2004 Nov 6]. 39p.Available from: http://www.usp.org/pdf/EN/consumers/guide.pdf.

24. McPherson A. and Macfarlane A. Quizzes and surveys. Ask about medicines. [Internet]. London:Teenage Websites Ltd;2003 [cited 2005 Nov 2]. Available from: www.doctorann.org/survey/

25. Hildebrand JR. TeensHealth:Understanding medications and what they do. [Internet]. US:Nemours Foundation's Center for Children's Health Media;2003 [cited 2005 Dec 4]. Available from: http://www.kidshealth.org/teen/your_body/medical_care/meds.html.

26. Gray N, McPherson A, MacFarlane A. 'Ask About Medicines': An online quiz for adolescents. [Internet]. UK:Health Services Research and Pharmacy Practice. 2005 [cited 2005 Jan 11]. Available from: http://www.hsrpp.org.uk/abstracts/2004_22.shtml.

27. Schickedanz JA, Schickedanz DI, Forsyth PD, Forsyth PA. Understanding children and adolescents. 3rd ed. Boston:Allyn and Bacon; 1998.

28. Gilbertson RJ, Harris E, Pandey SK, Kelly P, Myers W. Paracetamol use, availability, and knowledge of toxicity among British and American adolescents. Arch Dis Child. 1996;75(3):194-198.

29. Huott MA, Storrow AB. A survey of adolescents' knowledge regarding toxicity of over-the-counter medications. Acad Emerg Med. 1997;4(3):214-218.

30. Holstein BE, Hansen EH, Due P, Almarsdottir AB. Self-reported medicine use among 11-to 15- year-old girls and boys in Denmark 1988 -1998. Scand J Public Health. 2003;31:334-341.

31. Sanz EJ, Bush PJ, Garcia M. Medicines at home: the contents of medicine cabinets in eight countries. In: Bush PJ, Trakas DJ, Sanz EJ, Wirsing RL, Vaskilampi T, Prout A, editors. Children, Medicines and Culture. New York: Pharmaceutical Products Press; 1996.p. 77-104.

32. Allotey P, Reidpath D, Elisha D. "Social medication" and the control of children: a qualitative study of over-the-counter medication among Australian children. Pediatrics. 2004; 114(3):378-383.

33. Bauchner H, Pelton SI, Klein JO. Parents, physicians and antibiotic use. Pediatrics. 1999;103(2): 395-401.

34. Pechere JC. Patients' interviews and misuse of antibiotics. Clin Infect Dis. 2001;33(3): 170-173.

35. Bush PJ, Ozias JM, Walson PD, Ward RM. Ten guiding principles for teaching children and adolescents about medicines. Clin Ther. 1999;21(7):1280-1284.

36. Cordina M, McEInay JC, Hughes CM, Fenech AG. Health-related issues of importance to school children with asthma a qualitative study. J Soc Adm Pharm. 2002;19(5):162-169.

37. Van den Bulck J, Leemans L, Laekeman GM. Television and adolescent use of over-the-counter analgesic agents. Ann Pharmacother. 2005;39(1):58-62. 
38. Gray NJ, Klein JD, Noyce PR, Sesselberg TS, Cantrill JA. Health information-seeking behaviour in adolescence. Soc Sci Med. 2005; 60(7):1467-1478.

39. Population and social statistics unit. Demography review 2004: population and social conditions. Malta: National statistics unit; 2005.

40. Kitzinger J. Qualitative research: introducing focus groups. BMJ. 1995;311:299-302. 